\title{
Family reunification rights of (migrant) Union citizens: Towards a more liberal approach
}

\author{
Alina Tryfonidou*
}

\begin{abstract}
Over the years, in the case-law of the European Court of Justice (ECJ) determining the availability of family reunification rights for migrant Member State nationals, the pendulum has swung back and forth, from a 'moderate approach' in cases such as Morson and Jhanjan (1982) and Akrich (2003), towards a more 'liberal approach' in cases such as Carpenter (2002) and Jia (2007). Under the Court's 'moderate approach', family reunification rights in the context of the Community's internal market policy are only granted in situations where this is necessary for enabling a Member State national to move between Member States in the process of exercising one of the fundamental freedoms; in other words, where there is a sufficient link between the exercise of one of the fundamental freedoms and the need to grant family reunification rights under EC law. Conversely, under the Court's 'liberal approach', in order for family reunification rights to be bestowed by EC law it suffices that the situation involves the exercise of one of the fundamental freedoms and that the claimants have a familial link which is covered by the Community's secondary legislation: there is no need to illustrate that there is a link between the grant of such rights and the furtherance of the Community's aim of establishing an internal market. The recent Eind and Metock judgments (and the Sahin order) have shifted the pendulum towards the 'liberal approach' side by making it clear that it is not necessary a) that the family members of migrant economic actors have been lawfully resident in another Member State, prior to their move to the host State where they accompany or join the migrant; or b) (according to Metock and Sahin) that they have been family members of the migrant economic actor at the time that that person had exercised his freedom to move.
\end{abstract}

In this paper it will be explained that the fact that the EU is aspiring to be not only a supranational organisation with a successful and smoothly-functioning market but also a polity the citizens of which enjoy a number of basic rights which form the core of a meaningful status of Union citizenship, is the major driving force behind this move. In particular, the move towards a wholehearted adoption of the 'liberal approach' seems to have been fuelled by a desire, on the part of the Court, to respond to a number of problems arising from its 'moderate approach' and which appear to be an anomaly in a Citizens' Europe. These are: a) the incongruity caused between the (new) aim of the Community of creating a meaningful status of Union citizenship and the treatment of Union citizens (under the Court's 'moderate approach') as mere factors of production; and $b$ ) the emergence of reverse discrimination. The paper will

Dr Alina Tryfonidou, Lecturer in Law, University of Leicester. This is an updated and slightly amended version of an article that will be published in the European Law Journal. The paper will be presented at the EUSA conference in Los Angeles, on 24 April 2009. 
conclude with an explanation of why the adoption of the Court's liberal approach does not appear to be a proper solution to these problems.

\section{INTRODUCTION}

Over the years, in the Court's case-law determining the availability of family reunification rights under European Community (EC) law, the pendulum has swung back and forth from a 'moderate approach' in cases such as Morson and Jhanjan ${ }^{1}$ and Akrich, ${ }^{2}$ towards a more 'liberal approach' in cases such as Carpenter ${ }^{3}$ and Jia. ${ }^{4}$ Under the Court's 'moderate approach', family reunification rights in the context of the Community's internal market policy are only granted in situations where this is necessary for enabling a Member State national to move between Member States in the process of exercising one of the fundamental freedoms. Conversely, under the Court's 'liberal approach', in order for family reunification rights to be bestowed by EC law, it suffices that a situation involves the exercise of one of the fundamental freedoms ${ }^{5}$ and that the claimants have a familial link with a migrant Union citizen which is covered by the Community's secondary legislation ${ }^{6}$ - in other words, there is no need to show that there is a link between the grant of such rights and the furtherance of the Community's aim of establishing an internal market.

The recent Eind $^{7}$ and Metock $^{8}$ judgments (and the Order in Sahin ${ }^{9}$ ) have shifted the pendulum towards the 'liberal approach' side by making it clear that it is not necessary that the family members of migrant economic actors have been lawfully resident in another Member State, prior to their move to the host State where they

$1 \quad$ Joined Cases 35-36/82, Morson and Jhanjan v Netherlands [1982] ECR 3723.

Case C-109/01, Secretary of State for the Home Department v Akrich [2003] ECR I-9607.

Case C-60/00, Carpenter v Secretary of State for the Home Department [2002] ECR I-6279.

Case C-1/05, Yunying Jia v Migrationsverket [2007] ECR I-1.

In this paper, the term 'fundamental freedoms' will be used to refer only to the free movement of economically active persons provisions of the Treaty (i.e. Articles 39, 43 and 49 EC), and not to Article 18 EC which governs the free movement of economically inactive Union citizens. The ECJ itself appears to have made this distinction in its case-law (even though Article $18 \mathrm{EC}$ is considered to be one of the fundamental freedoms in broad terms - see section 1 on page 2 of the Commission's Report on the application of Directive 2004/38 on the rights of citizens of the Union and their family members to move and reside freely within the territory of the Member States, COM (2008) 840/3). See, for example, Case C-158/07, Förster v Hoofddirectie van de Informatie Beheer Groep, Judgment of 18 November 2008, not yet reported, para 37; Case C-403/03, Schempp v Finanzamt München, [2005] ECR I6421, para 18; Joined Cases C-11 and 12/06, Morgan and Bucher, [2007] ECR I-9161, para 23.

6 The categories of family members that have an automatic right to accompany or join the migrant in the host Member State can be found in Article 2(2) of Directive 2004/38 on the right of citizens of the Union and their family members to move and reside freely within the territory of the Member States, [2004] OJ L158/77.

Case C-291/05, Minister voor Vreemdelingenzaken en Integratie v R. N. G. Eind, [2007] ECR I-10719.

$8 \quad$ Case C-127/08, Metock and others v Minister for Justice, Equality and Law Reform, Judgment of 25 July 2008, not yet reported.

9 Case C-551/07, Sahin v Bundesminister für Inneres, Order of 19 December 2008, not yet reported. 
accompany or join the migrant; or (according to Metock and Sahin) that they have been family members of the migrant economic actor at the time that that person had moved to the host State.

It will be explained that the fact that the EU is aspiring to be, not only a supranational organisation with a successful and smoothly-functioning market, but also a polity the citizens of which enjoy a number of basic rights which form the core of a meaningful status of Union citizenship, is the major driving force behind this move. In particular, the move towards a wholehearted adoption of the 'liberal approach' seems to have been fuelled by a desire, on the part of the Court, to respond to a number of problems arising from its 'moderate approach' and which appear to be an anomaly in a Citizens' Europe. These are a) the incongruity caused between the (new) aim of the Community of creating a meaningful status of Union citizenship and the treatment of Union citizens (under the Court's 'moderate approach') as mere factors of production; and b) the emergence of reverse discrimination. The paper will conclude with an explanation of why the adoption of the Court's liberal approach does not appear to be a proper solution to these problems.

\section{FAMILY REUNIFICATION RIGHTS UNDER EC LAW: THE 'MODERATE' AND THE 'LIBERAL' APPROACHES}

Since the very early days of the Community's existence, the importance of ensuring that the family members of migrant Member State nationals are given certain rights (including family reunification rights) which are necessary for ensuring that the right to free movement of the migrant is not deprived of all useful effect, has been recognised. ${ }^{10}$ This 'tradition' has been carried forward throughout the decades and, as will be explained in this section, has been bolstered, and to a certain extent exceeded its four corners, in the last decade or so.

The family reunification rights 'saga' of the Court can be broadly divided into two 'groups' which follow two different approaches. On one end of the spectrum lies what I call the 'moderate approach' to the bestowal of family reunification rights, followed by the Court in cases such as Morson and Jhanjan ${ }^{11}$ and Akrich. ${ }^{12}$ On the other end of the spectrum, we have case-law which comprises the group characterised by a more liberal approach towards the conferral of family reunification rights (the 'liberal approach'). The most characteristic case of this latter group is the muchcriticised Carpenter judgment of $2002,{ }^{13}$ however, the 'liberal approach' seems to have been followed in all of the latest cases before the ECJ (Jia, Eind, Metock and Sahin $)^{14}$ and, therefore, it appears that the Court has (implicitly) decided to now adopt

\footnotetext{
10 G. Barrett, 'Family matters: European Community Law and third-country family members', (2003) 40 Common Market Law Review 369, 375-376. This was also mentioned by the Court in Carpenter, n 3 supra, para 38.

$11 \quad \mathrm{~N} 1$ supra.

$\mathrm{N} 2$ supra.

N 3 supra.

N 4 supra; n 7 supra; n 8 supra; n 9 supra, respectively.
} 
this approach to the bestowal of family reunification rights. As will be explained, it is not crystal clear to which group the Singh ${ }^{15}$ case was intended to belong, since this depends on the actual interpretation of that judgment and, as can be deduced from recent case-law (Akrich, Jia and Eind), this is a territory where great ambiguity still lurks.

Starting with the 'moderate approach', this is evident in cases where the Court required that the grant of family reunification rights was necessary for enabling a Member State national to move between Member States and exercise one of the fundamental freedoms. ${ }^{16}$ This approach was starkly illustrated in Morson and Jhanjan where the Court, applying the purely internal rule established in the Saunders case, ${ }^{17}$ held that Dutch nationals of Surinam origin, who had lived and worked throughout their whole lives in the Netherlands, did not derive an automatic right from EC law to be accompanied by their Surinamese mothers in the Netherlands. The reason behind this has, apparently, been that on the facts, the refusal to bestow a right of residence on the Surinamese women would in no way impact on the exercise by their children of one of the fundamental freedoms. Hence, in Morson the Court established that Member States are not required by EC law to grant family reunification rights in situations falling outside the scope of EC law because they are unrelated to the aims of the Treaty, and thus, in such instances, the fate of the right of residence of the family members of Member State nationals depends, entirely, on the national laws of the Member State on the territory of which a right of residence is claimed. This absolutely rational approach often gives rise to the problem of reverse discrimination ${ }^{18}$ since the immigration laws of most Member States are (often) more difficult to satisfy than the EC provisions which provide an automatic right to family reunification in situations falling within the scope of the free movement provisions. ${ }^{19}$

In order to proceed with the other major 'moderate approach' judgment, we need to take a chronological leap forward and travel from 1982, when the Morson and Jhanjan case was decided, to 2003 and the Akrich case. Akrich is, to its greatest part, ${ }^{20}$ a rationalising judgment. There, the Court confirmed that a national of a

Case C-370/90, The Queen v Immigration Appeal Tribunal and Surinder Singh, ex parte Secretary of State for the Home Department [1992] ECR I-4265.

As Advocate General Tesauro has very rightly observed in his Opinion in Singh, 'the simple exercise of the right of free movement within the Community is not in itself sufficient to bring a particular set of circumstances within the scope of Community law; there must be some connecting factor between the exercise of the right of free movement and the right relied on by the individual' (paragraph 5 of the Advocate's General Opinion in Singh, ibid). Case 175/78, $R$ v Saunders [1979] ECR 1129, para 11.

18 See paragraphs 53-57 of the Opinion of Advocate General Stix-Hackl in Carpenter, n 3 supra. For a detailed study on the problem of reverse discrimination in EC law see A. Tryfonidou, Reverse Discrimination in EC Law (Kluwer Law International, 2009).

Paragraphs 26 and 33 of the Opinion of Advocate General Geelhoed in Jia, n 4 supra. For a recent study on reverse discrimination in the context of family reunification in the EC see A. Walter, Reverse Discrimination and Family Reunification (Wolf Legal Publishers, 2008).

Although Akrich is considered to be a rationalising judgment as regards the Court's approach towards the bestowal of family reunification rights, nonetheless, the same does not hold true for the Court's approach in that judgment towards the scope of application of EC human rights protection. There the Court, after finding that Mr Akrich did not derive from EC law a right to 
Member State who returns to his State of nationality may be able to rely on EC law against that State in order to claim a right of residence for his family members. However, according to the Court, a right of family reunification in the territory of the destination State (whether this be the State of nationality of the migrant Member State national or any other Member State) must only be granted, by virtue of EC law, if the family member had been lawfully resident in the territory of a Member State from which she moved together with the migrant Member State national to the territory of the State where a right of residence is claimed. The reason behind this condition of prior lawful residence within the territory of the EU is obvious: if the aim of the grant of family reunification rights is, purely, to enable Member State nationals to move freely between Member States, the refusal of such rights can be considered as impeding that movement only if a Member State national who was, previously, residing lawfully with his family members in the territory of one Member State will, as a result of his movement to another Member State, lose the right to live together with his close family members. Conversely, if no such right was enjoyed in the territory of the State from which the migrant moved, then it seems that the refusal of a right of residence for family members in the receiving State would not have any impact on the exercise of the freedom to move and thus would not have a sufficient link with the economic aims of the fundamental freedoms. ${ }^{21}$

\section{B The 'liberal approach'}

In the cases of Jia and Carpenter the Court of Justice seems to have followed a more liberal approach by (implicitly) accepting that EC law may require the grant of family reunification rights even in situations when this is not necessary for, and in any way linked to, the exercise of free movement from one Member State to another.

Mr Carpenter was a British national who was providing services to persons established in other Member States, whilst retaining his permanent residence and business in the UK. The problems for Mr Carpenter began when his Philippines national wife applied for a permanent residence permit in the UK. The British authorities refused to grant Mrs Carpenter a residence permit on the ground that she did not satisfy the requirements of the UK legislation on the issue; and they issued a deportation order against her. When the issue reached the Court of Justice, the Court held that Article 49 EC required the UK to give the right to Mrs Carpenter to reside on its territory together with her husband as otherwise the latter's right to provide services to persons established in the territory of another Member State would be impeded. $^{22}$ As argued elsewhere, this was clearly a case where the grant of family reunification rights was not, in any way, necessary for enabling a Member State

family reunification in the UK, went on to note that when the relevant Member State would be making its assessment regarding the issue of whether family reunification rights should be granted under national law, it should have regard to the need to respect for the right to family life of those persons which is 'among the fundamental rights which [...] are protected in the Community legal order' (Akrich, n 2 supra, para 58). In this way, the Court extended the scope of application of human rights that are protected as general principles of EC law, to situations that fall outside the scope of EC law. For a criticism of this part of the Court's judgment in Akrich see C. Schiltz, 'Akrich: A clear delimitation without limits', (2005) 12(3) Maastricht Journal of European and Comparative Law 241, 250-251.

$21 \quad$ Akrich ibid paras. 50-54.

$22 \quad$ Carpenter, n 3 supra, para 39. 
national to exercise an inter-state economic activity. ${ }^{23}$ How can it be said that $\mathrm{Mr}$ Carpenter would cease travelling to other Member States in order to provide services (or, even more extraordinarily, stop providing services from the UK to persons established in other Member States), just because his wife was not given a right to reside in the UK? Mr Carpenter was not confronted with the dilemma of either not exercising his freedom to provide services and maintaining the right to reside with his wife, or exercising that freedom and, as a result of that, losing that right. ${ }^{24}$ The Court has, therefore, been castigated for its judgment in Carpenter for creating a situation whereby the limits of application of EC law have become incredibly uncertain. ${ }^{25}$

A very similar approach was followed by the Court subsequently in the Jia judgment. There, the failure of the host Member State (Sweden) to grant family reunification rights to the Chinese mother-in-law of a German national who had moved from Germany to its territory in order to exercise her freedom of establishment eight years before, did not seem capable of interfering with the exercise of the latter's freedom. Yet, the Court held that Ms Jia was entitled, under EC law, to be granted the right to accompany her daughter-in-law in Sweden. The main difference from Carpenter is that the State where the right of residence was claimed by the third country national, was not the State of nationality of the migrant worker. However, like in Carpenter, in Jia there was not a link between the failure to grant family reunification rights and a deterrent effect on the exercise of inter-state movement in furtherance of the Community's (economic) aims. How can it be said that a person who has exercised her freedom to move and establish business in the territory of another Member State, would be deterred if her mother-in-law from a non-EU country was not allowed to come directly to join her in the host Member State eight years after that initial movement? ${ }^{26}$

Hence, it seems that under this 'liberal approach', ${ }^{27}$ the mere proof of the existence of the requisite family link, together with the exercise of some kind of inter-state movement, suffices for the bestowal by the Treaty free movement of persons provisions of automatic family reunification rights on third-country nationals and their Member State national family members. ${ }^{28}$

\footnotetext{
23 See A. Tryfonidou, 'Jia or "Carpenter II": The edge of reason', (2007) 32 European Law Review 908, 914-915.

For commentators characterising the Court's reasoning in Carpenter as 'artificial' see S. Acierno, 'The Carpenter Judgment: Fundamental Rights and the Limits of the Community Legal Order', (2003) 28(3) European Law Review 398; N. Reich and S. Harbacevica, 'Citizenship and Family on Trial: A Fairly Optimistic Overview of Recent Court Practice with regard to Free Movement of Persons', (2003) 40 Common Market Law Review 615, 628. For an excellent explanation of why there was not a real link with EC law in Carpenter see L. Woods, Free Movement of Goods and Services within the European Community (Ashgate, 2004), 224

N. Foster, 'Family and welfare rights in Europe: the impact of recent European Court of Justice decisions in the area of the free movement of persons', (2003) 25(3) Journal of Social Welfare and Family Law, 291, 297.

See the Opinion of Advocate General Geelhoed in Jia, n 4 supra, paras. 70-71.

Other cases which can be included in this group are Case C-459/99, MRAX v État belge [2002] ECR I-6591; and Case C-157/03, Commission v Spain [2005] ECR I-2911.

For an analysis the problems that are caused as a result of the application of the Court's 'liberal approach' see A. Tryfonidou, 'Reverse Discrimination in Purely Internal Situations:
} 
The discussion brings us now to the controversial case of Singh, a case capable of two different interpretations which have divided commentators. Depending on the interpretation adopted, Singh can been characterised as a 'good' or a 'bad' decision.

It should be recalled that the Singhs got married in the early 1980s and were lawfully residing in the UK. Mr Singh was an Indian national and Mrs Singh was a British national. In 1983, the Singhs moved to Germany where Mrs Singh was employed (ie she was a 'worker' within the meaning of Article 39 EC). After a couple of years in Germany, the Singhs decided to return to the UK, where Mrs Singh established a business. When Mr Singh applied to the UK authorities for a residence permit, the latter rejected his application. The issue was then referred to the ECJ where it was pointed out:

A national of a Member State might be deterred from leaving his country of origin in order to pursue an activity as an employed or self-employed person [...] in the territory of another Member State if, on returning to the Member State of which he is a national in order to pursue an activity there as an employed or self-employed person, the conditions of his entry and residence were not at least equivalent to those which he would enjoy under the Treaty or secondary law in the territory of another Member State.

He would in particular be deterred from so doing if his spouse and children were not also permitted to enter and reside in the territory of his Member State of origin under conditions at least equivalent to those granted them by Community law in the territory of another Member State. ${ }^{29}$

These paragraphs have been interpreted by most commentators as stating that the refusal to bestow on Mr Singh a right to reside within the territory of the UK would deter Mrs Singh from moving in the first place from the UK to Germany. ${ }^{30}$ This interpretation of the case will hereinafter be referred to as 'Interpretation I' of Singh. Such an interpretation, obviously, makes Singh a bad decision. When the Singhs got married and lived in the UK, Mr Singh's right of residence in the UK was governed by UK law. When Mr Singh returned to the UK with Mrs Singh, his right was, again, governed by UK law. Therefore, the movement of the Singhs from the UK to Germany did not have any (negative) impact on Mr Singh's right of residence in the UK. Mr Singh's position was exactly the same as would have been, had Mrs Singh remained confined within the territory of the UK and had not moved to Germany in order to work.

An Incongruity in a Citizens' Europe', (2008) 35(1) Legal Issues of Economic Integration 43, 52-53.

29 Paras 19-20 of the judgment in Singh, n 15 supra.

30 See M. Poiares Maduro, 'The Scope of European Remedies: The Case of Purely Internal Situations and Reverse Discrimination' in C. Kilpatrick, T. Novitz and P. Skidmore (Eds.), The Future of European Remedies (Hart, 2000), 124-125; N. Nic Shuibhne, 'Free movement of persons and the wholly internal rule: Time to move on?', (2002) 39 Common Market Law Review 731, 744-748; L. Woods, n 23 supra, at 225. This appears also to be the view of Advocate General Stix-Hackl in her Opinion in Carpenter, n 3 supra, para 66. 
On the other hand, some other commentators, taking into account the specific facts of the case, have been of the view that the Court's judgment in Singh allows for a different interpretation ('Interpretation II' of Singh). ${ }^{31}$ According to them, if $\mathrm{Mr}$ Singh was refused the right to reside in the UK following Mrs Singh's return to the UK, Mrs Singh would be deterred from moving from Germany back to the UK in order to exercise her freedom of establishment. ${ }^{32}$ If this interpretation is accepted, then Singh falls within the 'moderate approach' since it becomes clear that if Mrs Singh knew that, on her return to the UK, she would lose the right she enjoyed in Germany of living with her husband, then it is highly likely that she would decide not to exercise her freedom to move from Germany back to her State of nationality in order to pursue a self-employed activity there. This interpretation seems to have been adopted, also, in the Akrich judgment where the Court examined whether the right of Mrs Akrich to return from Ireland to the UK (her State of nationality) in order to work, would be deterred as a result of the refusal of the UK authorities to allow $\mathrm{Mr}$ Akrich the right to reside in the $\mathrm{UK}^{33}$

\section{Eind, Metock and Sahin: Moving towards the 'liberal approach'}

The recent judgments of the Court in Eind and Metock (and its order in Sahin) appear to have decidedly moved the pendulum towards the 'liberal approach' side. Any considerations that the previous cases which are representative of this approach may have just been confined to their own facts, have now been removed. The Court has made it clear through its reasoning that, provided that a situation involves the exercise by a Union citizen of one of the fundamental freedoms and a family member who falls within one of the categories provided by secondary legislation, a sufficient link with EC law exists and thus the family member can automatically accompany or join the migrant in the host State, without any additional conditions being imposed by that State.

(i)

$\underline{\text { Eind }}$

In February 2000 Mr Runaldo Eind, a Dutch national, left the Netherlands and went to the UK in order to work. He was subsequently joined by his 11-year-old daughter Rachel, a national of Surinam, who joined him directly from her country of nationality. The UK authorities informed Mr Eind that, as a migrant worker, he had a right to reside in the UK by virtue of Regulation $1612 / 68,{ }^{34}$ and, at the same time, his daughter was informed that she also had, under the same legislation, a right to reside in the UK in her capacity as a member of the family of a Community worker. In October 2001, Mr Eind returned to the Netherlands and Rachel joined him there. In the Netherlands, Mr Eind was not engaged in any economic activity nor was he actively looking for a job. The Dutch State Secretary for Justice refused to issue a residence permit for Rachel pointing out that she did not derive any rights from EC

31

32

33

34

See, for example, G. Barrett, n 10 supra, at 379. White appears to be of the view that the Court's judgment can accommodate both interpretations - see R. C. A. White, 'A fresh look at reverse discrimination', (1993) 18(6) European Law Review 527.

This was also the view of Advocate General Tesauro in his Opinion in the Singh case (n 15 supra). Paragraph 21 of the Judgment in Singh may also be used in support of this interpretation.

Akrich, n 2 supra, paras. 47-48. See C. Schiltz, n 20 supra, at 247.

Regulation 1612/68/EEC on freedom of movement for workers within the Community, [1968] OJ L257/2. 
law as a family member of her father since her father was neither a 'worker' within the meaning of Article 39 EC nor a (economically inactive) Union citizen that fell within the scope of EC law. Therefore, the Dutch court hearing the case referred a number of questions to the ECJ which, in effect, asked whether Rachel had a right deriving from EC law to remain in the Netherlands as a family member of her father.

The Court held that Rachel had a right under EC law, and in particular the free movement of workers provisions, to accompany her father in the Netherlands and reside there. In the main part of its reasoning, the Court employed the 'deterrence principle' which was firstly applied in the Singh case. The Court began its analysis by explaining that

the right of the migrant worker to return and reside in the Member State of which he is a national, after being gainfully employed in another Member State, is conferred by Community law, to the extent necessary to ensure the useful effect of the right to free movement for workers under Article $39 \mathrm{EC}$ and the provisions adopted to give effect to that right, such as those laid down in Regulation 1612/68. [...]. ${ }^{35}$

The Court then moved on to explain this in more detail and pointed out in paragraphs 35 and 36 of its judgment that:

[a] national of a Member State could be deterred from leaving that Member State if he does not have the certainty of being able to return to his Member State of origin, irrespective of whether he is going to engage in economic activity in the latter State. That deterrent effect would also derive simply from the prospect, for that same national, of not being able, on returning to his Member State of origin, to continue living together with close relatives, a way of life which may have come into being in the host Member State as a result of marriage or family reunification.

Finally, the Court provided the clarification (though, in view of the lack of clarity of this part of the judgment, this appears to be an oxymoron) that the right of residence to which Rachel is entitled by virtue of EC law is not affected by the fact that, before residing in the host Member State, Rachel did not have a right of residence, under national law, in the Member State of nationality of Mr Eind. ${ }^{36}$ This, according to the Court, is due to the fact, firstly, that the basis for requiring such a right is not laid down, expressly or by implication, in any provision of Community law relating to the right of residence of third-country national family members of Community migrant workers; ${ }^{37}$ and, secondly, such a requirement would run counter to the objectives of the Community legislature, which has recognised the profound importance of ensuring protection for the family life of nationals of the Member States in order to eliminate obstacles to the exercise of the fundamental freedoms guaranteed by the Treaty. ${ }^{38}$

\begin{tabular}{ll}
\hline 35 & Eind, n 7 supra, para 32. \\
36 & Ibid para 41. \\
37 & Ibid para 43. \\
38 & Ibid para 44.
\end{tabular}


(ii)

Metock and Sahin

The Court in July 2008 delivered its judgment in Metock applying the accelerated procedure for which provision is made in Article 23a of the Statute of the Court of Justice. The judgment is more like a ruling of principle as in its reasoning the Court does not make reference to the actual facts of the cases from which the questions arose. As will be seen, the Court, in effect, repeated the reasoning (with some further clarifications) it had followed in Eind, thus cementing the 'liberal approach' to the grant of family reunification rights.

The reference was made in the course of four applications for judicial review before the Irish High Court, each seeking an order of certiorari quashing the decision of the Irish Minister for Justice, Equality and Law Reform refusing to grant a residence card to a national of a non-member country married to a Union citizen residing in Ireland. The facts of each of the cases involved a migrant Union citizen who held the nationality of another Member State and had moved to Ireland from that State and their third-country national spouse who had applied to the Irish authorities for a residence card. A common element in all cases was that the third-country-national spouse had not lawfully resided in the territory of another Member State prior to moving to Ireland and the marriage of the couple took place in Ireland after the thirdcountry-national entered the territory of that State. In all cases, the residence card was refused on the ground that the (third-country-national) applicants did not satisfy the condition of prior lawful residence in another Member State required by Irish legislation. The two main questions referred were: a) whether Directive 2004/38 ${ }^{39}$ precludes legislation of a Member State which requires a national of a non-member country who is the spouse of a Union citizen residing in that Member State but not possessing its nationality to have previously been lawfully resident in another Member State before arriving in the host Member State, in order to benefit from the provisions of that Directive; and, b) whether the spouse of a Union citizen who has exercised his right of freedom of movement by becoming established in a Member State whose nationality he does not posses accompanies or joins that citizen within the meaning of Article 3(1) of Directive 2004/38, and consequently benefits from the provisions of that Directive, irrespective of when and where the marriage took place and of the circumstances in which he entered the host Member State.

As regards the first question, the Court replied that Directive 2004/38 precludes legislation of a Member State which requires a national of a non-member country who is the spouse of a Union citizen residing in that Member State but not possessing its nationality to have previously been lawfully resident in another Member State before arriving in the host Member State, in order to benefit from the provisions of that Directive. It began its analysis by stating that no provision of the 2004 Directive makes the application of that piece of legislation conditional on their having previously resided in a Member State ${ }^{40}$ and subsequently cited some of the provisions of the Directive to support this statement. ${ }^{41}$ It noted, in particular, that the Court's previous pronouncement in Akrich that, in order to benefit from the family reunification rights provided in secondary Community legislation, the national of a non-member country must be lawfully resident in a Member State when he moves to

\begin{tabular}{ll}
\hline 39 & N 6 supra. \\
40 & Metock n 8 supra, para 49. \\
41 & Ibid paras 50-54.
\end{tabular}


another Member State to which the citizen of the Union is migrating, 'must be reconsidered'. ${ }^{42}$ The Court further pointed out that this interpretation is consistent with the division of competences between the Member States and the Community. ${ }^{43}$ Since the Community has competence to bring about freedom of movement for Union citizens $^{44}$ and since 'if Union citizens were not allowed to lead a normal family life in the host Member State, the exercise of the freedoms they are guaranteed by the Treaty would be seriously obstructed', ${ }^{45}$ this, according to the Court, means that it is within the competence conferred on the Community legislature to 'regulate the conditions of entry and residence of the family members of a Union citizen in the territory of the Member States, where the fact that it is impossible for the Union citizen to be accompanied or joined by his family in the host Member State would be such as to interfere with his freedom of movement by discouraging him from exercising his rights of entry into and residence in that Member State'. ${ }^{46}$ The Court, then, noted that 'the refusal of the host Member State to grant rights of entry and residence to the family members of a Union citizen is such as to discourage that citizen from moving to or residing in that Member State, even if his family members are not already lawfully resident in the territory of another Member State'. ${ }^{7}$

As regards the second question, the Court replied that 'the words "family members [of Union citizens] who accompany ... them" in Article 3(1) of that directive must be interpreted as referring both to the family members of a Union citizen who entered the host Member State with him and to those who reside with him in that Member State, without it being necessary, in the latter case, to distinguish according to whether the nationals of non-member countries entered that Member State before or after the Union citizen or before or after becoming his family members'. ${ }^{48}$ According to the Court, this is due to the fact that '[w] here a Union citizen founds a family after becoming established in the host Member State, the refusal of that Member State to authorise his family members who are nationals of non-member countries to join him there would be such as to discourage him from continuing to reside there and encourage him to leave in order to be able to lead a family life in another Member State or in a non-member country'. ${ }^{49}$

\footnotetext{
$42 \quad$ Ibid para 58.

$43 \quad$ Ibid para 60.

$44 \quad$ Ibid.

$45 \quad$ Ibid para 62.

$46 \quad$ Ibid para 63.

47 Ibid para 64. It is, also, quite interesting to note that the Court itself argued that the requirement of prior lawful residence for family members of migrant Union citizens would lead to reverse discrimination against Union citizens when compared to third-countrynationals falling within the scope of Directive 2003/86 on the right to family reunification, [2003] OJ L251/12, since that piece of legislation requires Member States 'to authorise the entry and residence of the spouse of a national of a non-member country lawfully resident in its territory where the spouse is not already lawfully resident in another Member State' (para. 69 of Metock).

$48 \quad$ Metock, ibid, para 93.

$49 \quad$ Ibid para 89.
} 
The (even more recent) Sahin case involved facts which were very similar to those in the Metock cases. ${ }^{50}$ There, the applicant - Mr Sahin - was a Turkish national who was refused by the Austrian authorities a permanent residence card on the ground that he did not derive from EC law the right to accompany his German wife in Austria. This was, mainly, because Mr Sahin's wife had exercised her right to free movement (from Germany to Austria) at a time when Mr Sahin was already residing in Austria and thus, in effect, Mr Sahin was not joining or accompanying a migrant Union citizen in the host State when he moved to Austria; and Mr Sahin and his wife got married in 2006, i.e. three years after Mr Sahin and two years after his wife, entered Austria (therefore, Mr Sahin acquired the status of family member under EC law only at that time and, thus, after he moved to Austria). In its Order, the Court in effect copied and pasted its reasoning from Metock and replied that Directive 2004/38 must be interpreted as applying also to family members who arrived in the host Member State independently of the Union citizen and acquired the status of family member or started to lead a family life with that Union citizen only after arriving in that State.

\section{$\underline{\text { Eind, Metock, Sahin and the 'liberal approach' }}$}

It is my thesis that both of the most recent judgments of the Court - Eind and Metock - on family reunification rights arising as a result of the exercise of one of the fundamental freedoms, as well as the Order of the Court which merely replicated the Court's judgment in Metock (Sahin), fall squarely within the 'liberal approach'.

In the first of these cases - Eind - the Court seems to have been determined to clarify a number of outstanding issues, the most important ones being whether the Akrich condition should be applied as a general condition in family reunification cases; and, more implicitly, which interpretation of Singh should prevail.

In its written observations in Eind, the Netherlands government emphasised that $\mathrm{Mr}$ Eind could not have been deterred from exercising his freedom to move to the UK in order to take up gainful employment, by the fact that it would be impossible for his daughter to reside with him once he returned to his Member State of origin, 'given that at the time of the initial move Miss Eind did not have a right to reside in the Netherlands'.51

In reply to that point, the Court noted that that approach cannot be accepted and, as already seen, making use of the 'deterrence principle' and applying reasoning akin to 'Interpretation I' of Singh, ${ }^{52}$ it pointed out that Mr Eind's right to exercise his initial

$50 \quad$ The only difference of substance is that Mr Sahin enjoyed a temporary right of residence in Austria under the laws on asylum. However, since this is not important for our purposes, it will not be discussed further on the main text.

$51 \quad$ Eind $\mathrm{n} 7$ supra, para 33.

52 In his Opinion in the Eind case, ibid, Advocate General Mengozzi also adopted 'Interpretation I' of Singh - see, in particular, para 97 of the Opinion. It should be noted that although the Advocate General applied the 'deterrence principle' in the same way as the Court (see paras. 101-103 of the Opinion), nonetheless he complemented his reasoning by looking at alternative ways for bringing the situation within the scope of EC law: (a) he examined whether Rachel could derive from EC law a right of residence in the Netherlands as a family member of a jobseeker; and (b) he enquired whether Rachel could, in the alternative, derive a right of 
movement from the Netherlands to the $U K$ as a worker, would have been deterred as a result of the refusal of the Netherlands to grant a right of residence to Rachel. As regards, in particular, the Akrich condition of prior lawful residence in the territory of a Member State, the Court observed, somewhat ambiguously, that the fact that Rachel was not lawfully resident in the territory of the Netherlands prior to moving to the UK, does not affect the finding that Mr Eind would be deterred from moving from the Netherlands to the UK in case the former State refused to grant Rachel a right of residence on his return. ${ }^{53}$ This appears to have been a subtle affirmation of the principle established in $\mathrm{Jia}$, that the application of the 'Akrich condition' should be confined to cases involving facts similar to Akrich. ${ }^{54}$

Moreover, in practical terms, the facts in Eind do not appear to involve a sufficient link with EC law. More specifically, there does not seem to be any link between the exercise by Mr Eind of his right under Article $39 \mathrm{EC}$ to move from his home State to the UK to work, and the refusal of the Netherlands to grant his daughter a right to reside in its territory on his return from the UK. In other words, the refusal of the Dutch authorities to grant Rachel a residence permit did not come as a result of $\mathrm{Mr}$ Eind's movement to the UK. Rachel did not enjoy a right of residence in the Netherlands before Mr Eind exercised his freedom of movement to the UK and, similarly, on Mr Eind's return to the Netherlands, the Dutch authorities applying Dutch law, did not grant her a right of residence. Hence, the exercise by Mr Eind of his right to move to another Member State to work could not have been deterred as a result of the Dutch authorities' refusal to grant his daughter a residence permit in the Netherlands.

To dispel any remaining doubts following Eind, the Court in Metock made it absolutely clear that not only is it not required that the Akrich condition is satisfied in order for family reunification rights to arise as a matter of EC law but, moreover, the imposition of such a condition of prior lawful residence by the legislation of a Member State is in violation of EC law and, in particular, the 2004 Directive. ${ }^{55}$ This was also affirmed in the Court's Order in Sahin. Moreover, Metock and Sahin provided the further clarification that even if the third-country-national applicant for a residence permit has become a family member of the migrant Union citizen (i.e. the 'sponsor' of the rights) after he entered the territory of the host State, he still can qualify for a derived right of residence as a family member of the migrant.

residence in the Netherlands as a family member of a migrant Union citizen falling within the scope of Article 18 EC read in conjunction with Directive 90/364 on the right of residence, [1990] OJ L180/26. Perhaps the Advocate General was suspecting that the Court might prefer to apply its 'moderate approach' in the case and require a real link between the refusal of the grant of family reunification rights and the exercise of an inter-state economic activity and, therefore, in such an instance, the free movement of workers provisions and the 'deterrence principle' would be of no use to the Einds.

53 Eind, ibid, paras. 41-44.

54 This is more directly expressed in the Opinion of Advocate General Mengozzi in Eind, ibid, paras. 42-46.

55 It is not clear whether the imposition of such a condition of prior lawful residence would, also, violate primary legislation (e.g. Article $39 \mathrm{EC}$ ) applied to situations which do not fall within the scope of Directive 2004/38 (n 6 supra), i.e. situations which fall within the scope of the Treaty provisions on the free movement of persons but which do not fall within the scope of Directive 2004/38 because they do not involve a Union citizen moving to a Member State other than that of his nationality (see Article 3(1) of the 2004 Directive). 
When applying these principles to the facts of the cases from which the questions referred arose, it can be seen that the Court appears to have totally abandoned the requirement of the existence of a link between the exercise of one of the fundamental freedoms and the grant of family reunification rights to the Union citizen who has exercised that fundamental freedom. On the facts of all these cases (ie the Metock group of cases and Sahin), it was obvious that the loss of the right to be with (certain) family members was not in any way related to the exercise of the freedom of movement of workers under Article $39 \mathrm{EC}$ by the spouses of the applicants. The Union citizens who were the family members of the applicants did not enjoy a right of being with their family members in the State from which they came, simply because the applicants became members of the family of the migrant 'sponsor' only once the latter moved to the territory of the host State. And even if the applicants were, already, members of the family of the migrant Union citizens at the time of the latters' move to the host State, still, a sufficient link with the exercise of movement as a worker would not be established since in all cases the right to be with their thirdcountry-national spouses was not lost as a result of the exercise of the relevant fundamental freedom, precisely because such as a right was not enjoyed in the first place. Hence, like in all the other 'liberal approach' cases, the Court seems to have been satisfied that the situations fell within the scope of EC law and, in particular, the free movement of workers provisions and Directive 2004/38, merely because they involved a Member State national who had exercised one of the fundamental freedoms and the (third-country-national) applicants fell within one of the groups of family members (i.e. spouses) that automatically enjoy the right under EC law to accompany their spouses in the host State.

Finally, if, following Eind, 'Interpretation I' of Singh is now adopted, this will mean that Singh can be added to the 'liberal approach' group, thus reinforcing the view (implicitly) held by the Court in Jia and Carpenter and, more recently, Eind, Metock and Sahin that, provided that some kind of inter-state movement has taken place, family reunification rights must be granted, even if their refusal would have in no way deterred the exercise of that movement. Accordingly, since the most recent cases of the Court on the issue of the bestowal of family reunification rights fall squarely within the 'liberal approach', it seems that we are witnessing a move towards a complete adoption of that approach. As will be seen in the subsequent part of this paper, the Court may have not been entirely unjustified in adopting this more flexible approach. In other words, the fact that the Court may now be eager to make family reunification rights (as part of the right to family life) more widely available, may be due to the need to ensure that some new (non-economic) objectives of the Community are furthered. ${ }^{56}$ And it is to the explanation of this that we now turn.

\section{THE RATIONALE BEHIND THE MOVE TOWARDS THE 'LIBERAL APPROACH'}

As it is undoubtedly well-known, the immediate aim of the drafters of the $\mathrm{E}(\mathrm{E}) \mathrm{C}$ Treaty back in the late 1950s was the creation of a common market. Therefore, when the Community legislature in the 1960s and early 1970s made provision for the grant of family reunification rights to migrant economic actors, it was acting as an

56 For another commentator advocating this view see G. Barrett, n 10 supra, at 419. 
institution of an economic organisation that viewed Member State nationals merely as instruments to be used in promoting its economic objectives. Accordingly, back then, Community legislation bestowed family reunification rights solely in order to encourage Member State nationals to move between Member States and exercise one of the (economic) fundamental freedoms, furthering in that way the Community's economic aims. ${ }^{57}$

However, it appears that, latterly, the Court of Justice is making its first tentative steps towards articulating a new aim for the Community. ${ }^{58}$ This new aim is the creation of a meaningful status of Union citizenship: a status which, following the recent pronouncements of the Court on the issue, does, indeed, appear to be a 'source of rights ${ }^{59}$ for Union citizens. ${ }^{60}$ Cases such as Martínez Sala ${ }^{61}$ Trojani, $^{62}$ and Bidar ${ }^{63}$ (to name but a few) illustrate how in the EU of today rights can be derived from the EC Treaty by Member State nationals (now Union citizens), even in situations which do not involve any kind of contribution to the economic aim of the Treaty of establishing and maintaining a single market. ${ }^{64}$ Such rights include the rights of free movement, residence, and non-discrimination on the grounds of nationality. ${ }^{65}$ However, it would seem that a meaningful notion of citizenship, such as the one that the Court of Justice appears to be wishing to construct, requires the EC to include some other basic rights in the list of rights that must now be made available to Union citizens. In particular, fundamental human rights, such as those enlisted in the European Convention on Human Rights (ECHR), are obvious candidates for inclusion within this list. Having in mind that some of the rights that have traditionally been granted to migrant economic actors have been extended to all Union citizens who can point to a link with EC law, there does not seem to be a valid reason for not extending other rights (such as traditional human rights) that have already been granted by EC law to migrant economic actors, to all Union citizens falling within the Community's ambit.

The central argument of this paper is that the real purpose of the Court in the 'liberal approach' cases of Carpenter, ${ }^{66} \mathrm{Jia}^{67}{ }^{6}$ Eind,${ }^{68}$ Metock $^{69}$ and Sahin ${ }^{70}$ may have simply been to protect the (human) right to family life (of which the right to family

\footnotetext{
$57 \quad$ See para. 69 of Advocate General Geelhoed's Opinion in Jia, n 4 supra; G. Barrett ibid at 375-376.

$58 \quad$ See A. Tryfonidou, n 28 supra, at 55.

59 S. Besson and A. Utzinger, 'Introduction: Future Challenges of European Citizenship - Facing a Wide-Open Pandora's Box', (2007) 13(5) European Law Journal 573, at 579.

$60 \quad$ N. Reich and S. Harbacevica, n 24 supra, at 617.

$61 \quad$ Case C-85/96, Martínez Sala v Freistaat Bayern [1998] ECR I-269

Case C-456/02, Trojani v Centre public d'aide sociale de Bruxelles [2004] ECR I-7573.

Case C-209/03, $R$ (ex parte Bidar) v London Borough of Ealing and Secretary of State for Education and Skills [2005] ECR I-2119

For an explanation see A. Tryfonidou, n 28 supra, at 55-60.

N. Foster, n 25 supra, at 295.

N 3 supra.

$\mathrm{N} 4$ supra.

N 7 supra.

N 8 supra.

N 9 supra.
} 
reunification is an aspect), of the Union citizens involved. All these cases involved moving Union citizens, Union citizens who had exercised one of the (economic) fundamental freedoms, the situation of which, however, did not present any real link with the economic aims of those freedoms. Accordingly, the real underlying aim of the Court in those cases may not have been to protect the economic fundamental freedoms of the claimants, but rather, to ensure that their right to respect for family life would not be arbitrarily limited by Member States. ${ }^{71}$

Hence, perhaps deciding to follow the suggestion of Advocate General Jacobs in the Konstantinidis case, ${ }^{72}$ the Court may be diffidently moving towards developing a new principle according to which all moving Union citizens must have their human rights respected as a matter of EC law. ${ }^{73}$ And it appears that in the Court's view, the kind of movement involved is not significant and thus, even those who move back to their State of nationality (such as Mr Eind) and those who exercise merely temporary shortterm movements to other Member States (such as Mr Carpenter), can rely on EC law for requiring Member States (including their own Member State) to respect their human rights. This development does not seem to be such a surprising step to take, in view of the fact that human rights considerations now deeply inform the choices of the Community institutions in formulating and applying Community law. ${ }^{74}$

\section{THE PROBLEMS WITH THE COURT'S LIBERAL APPROACH}

Yet, despite the attractiveness of this solution which adds an extra layer of human rights protection for (some) Union citizens, we immediately have to confront two not easily solvable - problems.

The first problem is the aggravation of the problem of reverse discrimination. As already briefly mentioned, the application of the purely internal rule which excludes from the scope of the Community's fundamental freedoms any situations that do not involve a link with EC law, often leads to the emergence of reverse discrimination. This difference in treatment affects a number of areas of everyday life since it may relate to a variety of matters such as conditions of employment, ${ }^{75}$ qualifying requirements for a profession, ${ }^{76}$ and, more importantly for our purposes, the

71 The importance attached by the Court in ensuring the protection of the family life of nationals of the Member States who have exercised one of the fundamental freedoms can be seen in most of the Court's case-law on family reunification rights, especially the most recent cases see, for instance, Metock, n 8 supra, para 56; Eind, n 7 supra, para 44; Carpenter, n 3 supra, para 38; MRAX, n 27 supra, para 53.

72 Case C-168/91, Konstantinidis v Stadt Altensteig, Standesamt, and Landratsamt Calw, Ordnungsamt [1993] ECR I-1191, para 46.

73 For a similar view see C. Schiltz, n 20 supra, at 251-252.

74 See, for example, the recent Family Reunification Directive (Directive 2003/86, n 47 supra), para 2 of the Preamble; Directive 2004/38, n 6 supra, para 31 of the Preamble.

75 Case C-332/90, Steen v Deutsche Bundespost [1992] ECR I-341.

76 Joined Cases C-29/94, C-30/94, C-31/94, C-32/94, C-33/94, C-34/94 and C-35/94, Criminal proceedings against Aubertin and others [1995] ECR I-301. 
availability of human rights ${ }^{77}$ and, in particular, family reunification rights. ${ }^{78}$ The Court seems to have been aware of the invidious results arising from this and, by following a more flexible approach in cases such as Carpenter ${ }^{79}$ and Eind, ${ }^{80}$ may have been aiming at preventing the emergence of reverse discrimination, at least in the context of family reunification rights. Indeed, the fact that it is now overly easy for a situation to be included within the scope of EC law means that, in arithmetic terms, much fewer instances of reverse discrimination will emerge. Yet, this does not solve the reverse discrimination conundrum in its entirety and, in reality, the new way employed in the 'liberal group' cases for determining which situations must qualify for EC protection, seems to be worsening the injustice caused as a result of the application of the purely internal rule. ${ }^{81}$

Since the Court may have decided to extend EC human rights protection to all moving Union citizens (or, following Chen, ${ }^{82}$ Garcia Avello, ${ }^{83}$ and Schempp, ${ }^{84}$ it could be suggested that this would be extended to all Union citizens who can point to a link with more than one Member State), it is obvious that Union citizens who fail to satisfy those linking requirements will continue to be excluded from that protection. ${ }^{85}$ This situation, however, is on a collision course with the deeply embedded view that human rights are rights that must be granted to all human beings, without any unjustifiable distinctions being made. At a time when the Community's (economic) fundamental freedoms were interpreted as including within their scope only situations that had a real link with their aim of establishing an internal market, it appeared to be justified to exclude from their scope any situations that did not present a link with that aim. Nonetheless, since, in a number of cases, the Court has included within the scope of the free movement of economic actors provisions situations that do not, in reality, present a link with their economic aims, the emerging difference in treatment between situations that fall within the scope of EC law (despite the fact that they only involve an artificial link with the aim of those provisions) and situations that continue to be excluded, appears to be entirely unjustified, since it is not based on the rational criterion of including within the scope of those provisions only situations that involve

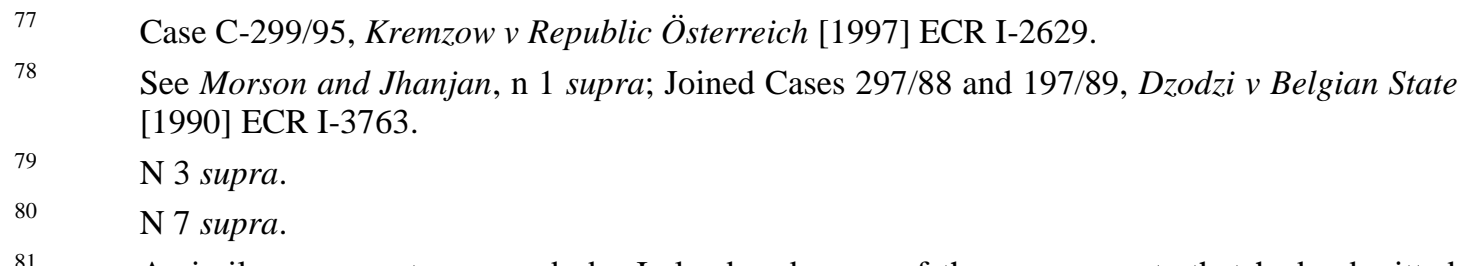

81 A similar argument was made by Ireland and some of the governments that had submitted observations in the Metock case (see para 76 of Metock, n 8 supra). In response to this argument the Court merely repeated the classic statement that the Treaty rules governing freedom of movement for persons and the measures adopted to implement them cannot be applied to activities which have no factor linking them with any of the situations governed by Community law and which are confined in all respects within a single Member State' (para. 77 in Metock) and '[a]ny difference in treatment between those Union citizens and those who have exercised their right of freedom of movement, as regards the entry and residence of their family members, does not therefore fall within the scope of Community law' (para 78).

82 Case C-200/02, Kunqian Catherine Zhu and Man Lavette Chen v Secretary of State for the Home Department [2004] ECR I-9925.

83 Case C-148/02, Garcia Avello v État belge [2003] ECR I-11613.

$84 \quad$ Schempp n 5 supra.

85 This problem was identified by Advocate General Jacobs in his Opinion in Konstantinidis, $\mathrm{n}$ 72 supra, para 47, but the Advocate General was of the view that this problem should not hinder the extension of human rights protection in the way he suggested (para 49). 
a true link to their aim. ${ }^{86}$ The same can be argued in relation to the way that the scope of application of the EC Treaty's Citizenship provisions has been drawn and, in particular, in relation to the acceptance in Chen that the mere possession of the nationality of one Member State whilst residing in the territory of another, can bring a Union citizen within the scope of EC law. ${ }^{87}$ Although a case involving this more lax linking factor and the application of EC human rights protection has not, yet, arisen, nonetheless, it is not difficult to perceive that there does not appear to be a rational justification for requiring, as a matter of EC law, a Member State to respect and protect the human rights of a Union citizen who happens to satisfy that link, whilst not having a similar obligation towards a Union citizen who fails to do so.

The fact that some Union citizens, without a valid justification, are excluded from the human rights protection that is made available by EC law, will surely present problems in a polity which aspires to create a meaningful notion of Union citizenship. $^{88}$ If the Court will expressly pronounce the principle that this author suspects has formed the rationale behind the Court's 'liberal approach' in family reunification judgments (ie that all moving Union citizens must, as a matter of EC law, have their human rights respected), it is highly probable that Union citizens who will be unable to benefit from that principle because their situation (quite arbitrarily) qualifies as purely internal to a Member State, will challenge it as being contrary to EC law. The argument will be that reverse discrimination is an unjustified difference in treatment ${ }^{89}$ that conflicts with the Community principle of equality between Union citizens. $^{90}$

86 For a commentator explaining the need for 'a criterion of reasonableness implicit in the scope of the Treaty' which may be used to justify a difference in treatment (including reverse discrimination) in EC law see E. Cannizzaro, 'Producing "Reverse Discrimination" through the exercise of EC competences', (1997) 17 Yearbook of European Law 29, 41-42.

Chen, n 75 supra, para 19. For a criticism of this see A. Tryfonidou, 'Kunqian Catherine Zhu and Man Lavette Chen v. Secretary of State for the Home Department: Further cracks in the “Great Wall” of the European Union?' (2005) 11(4) European Public Law 527, 540-541. For a commentator who wonders whether it makes sense to insist on a transboundary element for a situation to fall within the scope of the fundamental freedoms, in view of the trend followed in the Court's case-law where it is overly easy to establish a transboundary element see A. Epiney, 'The Scope of Article 12 EC: Some Remarks on the Influence of European Citizenship', (2007) 13(5) European Law Journal 611, 616-617.

Eeckhout has pointed out that the concept of EU citizenship, and its underlying rationale, will form a major force behind the conferral of fundamental (human) rights on the moving European citizen. However, he very rightly goes one step further in his analysis and argues that if fundamental (human) rights are conferred on the moving European citizen then this, undoubtedly, will lead to the further question of whether it remains permissible to differentiate between moving Union citizens and Union citizens who stay still - see P. Eeckhout, 'The EU Charter of Fundamental Rights and the Federal Question', (2002) 39 Common Market Law Review 945, at 972.

Opinion of Advocate General Geelhoed in Jia, n 4 supra, para 75. See also A. Tryfonidou, $\mathrm{n}$ 28 supra, at 60-64; N. Nic Shuibhne, 'The European Union and Fundamental Rights: Well in Spirit but Considerably Rumpled in Body?' in P. Beaumont, C. Lyons and N. Walker (eds.), Convergence and Divergence in European Public Law (Hart, 2002), 177, at 192.

For a view that reverse discrimination should, now, be prohibited in view of the development of the status of Union citizenship see F. G. Jacobs, 'Citizenship of the European Union - A Legal Analysis' (2007) 13(5) European Law Journal 591, 598. See, also, S. Besson and A. Utzinger, n 59 supra, at 583-584. 
The second difficulty arising from the Court's 'liberal approach' and its underlying objective of extending the availability of human rights to all Union citizens who can point to a link with more than one Member State, has to do with the possibility of carrying forward that approach in the near future and, more specifically, once the important constitutional developments that are in the EU's doorstep will take effect.

Through its case-law, the Court of Justice has required, on the one hand, the Community institutions, and, on the other hand, the Member States when acting as agents of the Community ${ }^{91}$ and when derogating from Community law requirements, ${ }^{92}$ to respect the human rights of Member State nationals, provided that their situation falls within the scope of EC law. ${ }^{93}$ However, the EU Charter of Fundamental Rights, ${ }^{94}$ which will become binding once and if the Lisbon Reform Treaty is ratified by all Member States, ${ }^{95}$ may have the effect of restricting the circumstances under which Member States are bound by human rights guarantees, as a matter of EC law. This is because Article 51(1) of the Charter provides that ' $[\mathrm{t}] \mathrm{he}$ provisions of this Charter are addressed to the institutions, bodies, offices and agencies of the Union [...] and to the Member States only when they are implementing Union law'. ${ }^{96}$ The lack of clarity in the Court's case-law as to what constitutes 'implementation of EC law' means that it is not clear whether the Charter will consolidate the Court's case-law and apply, inter alia, to situations involving Member States acting 'within the scope of application' of Community law (including situations involving Member States derogating from EC law (ERT-type situations)); or whether the drafters of the Charter intended to adopt a more restrictive approach than the one currently employed by the Court and limit the Charter's scope of application to agency, Wachauf-type, situations which involve implementation stricto sensu. ${ }^{97}$ The latter would allow within the scope of the Charter only situations involving a Member State applying a Community measure (eg a Community Regulation) or applying national legislation which has been drafted in order to implement into national law a piece of Community secondary legislation. ${ }^{98}$

\footnotetext{
$91 \quad$ Case 5/88, Wachauf v Germany [1989] ECR 2609.

92 Case C-260/89, ERT AE v Dimotiki Etairia Pliroforissis and Sotirios Kouvelas [1991] ECR I2925; Case C-368/95, Vereinigte Familiapress Zeitungsverlags- und Vertriebs GmbH v Heinrich Bauer Verlag [1997] ECR I-3689.

\section{[2007] OJ C 303/1}

Kremzow, n 77 supra.

Treaty of Lisbon amending the Treaty on European Union and the Treaty establishing the European Community, [2007] OJ C 306/1. See Article 1 of the Lisbon Treaty, in particular, the new Article 6(1) of the TEU, as will be amended following the Lisbon Treaty coming into force.

Emphasis added.

See P. Eeckhout, n 88 supra, at 977; P. Craig and G. de Búrca, EU Law: Text, Cases and Materials, (OUP, 2008), 402. Writing in 2001, Gráinne de Búrca noted that the drafting process of Article 51(1) of the Charter 'illustrates an emergent reluctance to commit the Member States to observing the norms of the Charter other than in the cases which are most closely linked to the European Union where the Member States have little or no autonomy, ie the actual implementation of European Union legislation' - see G. de Búrca, 'The drafting of the European Union Charter of Fundamental Rights', (2001) 26(2) European Law Review 126, 137.

It should be noted that the 'Explanations relating to the Charter of Fundamental Rights' document has not shed any further light on this question but has, in fact, complicated the situation by employing a term which has not previously been used in the case-law of the Court
} 
In case Article 51(1) of the Charter is interpreted in the latter, restrictive way, this will make it highly questionable whether the Court will be able to carry forward the principle that all Union citizens whose situation presents a link with more than one Member State, are entitled to EC human rights protection. This is because, as a result of this restrictive interpretation of Article 51(1), whenever a situation does not involve a Member State applying a Community legislative measure or applying national legislation which transposes EC legislation into national law, the Union citizen involved will not be able to rely on the Charter to challenge the way in which that Member State acts. In other words, if that interpretation prevails, only Union citizens who can point to a link with EC law and whose situation involves a Member State implementing EC law in either of the two ways provided above, will be able to rely on the Charter.

The area of family reunification rights provides the perfect example for illustrating the problems arising from the above restrictive interpretation of the Charter. In some of the family reunification cases that we saw in this piece (Singh, ${ }^{99}$ Carpenter, Akrich ${ }^{100}$ and Eind), it is clear that the contested actions in no way involved Member States 'implementing Union law'. This was because the facts of those cases involved Member State nationals who wished to be accompanied by their family members in their Member State of nationality, and the EC secondary legislation instruments that governed, inter alia, the conditions for the grant and restriction of family reunification rights at the time, ${ }^{101}$ only covered situations which involved Member State nationals who wished to be joined by their family members in Member States other than that of their nationality. This legislative lacuna seems to persist, even following the enactment of Directive 2004/38 ${ }^{102}$ which is, now, the sole Community legislative instrument that governs the grant of family reunification rights to Union citizens, and which provides in Article 3 that it applies to all Union citizens who move to, or reside in, a Member State other than that of which they are a national. Hence, since there is no piece of secondary legislation which governs the grant and restriction of the rights of family reunification of Union citizens wishing to rely on those rights against their State of nationality (eg Carpenter), it appears that in such cases, the Charter will not be applicable. Conversely, in situations involving a Union citizen who wishes to be accompanied by his family members in another Member State (eg Jia, Metock and Sahin $)^{103}$ the Charter may be applicable, since when the host Member State will be applying the conditions for the grant of, or when restricting, rights to family reunification of Union citizens in its territory, it will be applying national legislation which was drafted in order to implement Directive 2004/38.

and which is capable of actually broadening the scope of application of the Charter (and, in general, EU human rights protection) as regards acts of the Member States: 'the requirement to respect fundamental rights defined in a Union context is only binding on the Member States when they act in the context of Community law' (emphasis added) - See 'Explanations relating to the Charter of Fundamental Rights of the European Union', CONVENT 49, Charte 4473/00, at p. 46.

$\mathrm{N} 15$ supra.

N 2 supra.

Regulation 1612/68, n 34 supra; and Directive 73/148 Directive on the abolition of restrictions on movement and residence within the Community for nationals of Member States with regard to establishment and the provision of services, [1973] OJ L172/14.

N 6 supra.

$\mathrm{N} 4$ supra; $\mathrm{N} 8$ supra and $\mathrm{N} 9$ supra, respectively. 
This will, obviously, create another unjustifiable division as regards the availability of EC human rights protection, this time, however, the division will be between two categories of persons, both of which are comprised of Union citizens that fall within the scope of EC law. In the same way that reverse discrimination regarding the respect and protection of human rights is, in the light of recent developments, no longer a justified difference in treatment, the difference in treatment in this context, likewise, does not appear to be based on any justifiable ground. The mere fact that someone's situation happens to involve the implementation by a Member State of EC law, does not appear to be a rational ground on which to determine whether the Member State has to protect and respect human rights as enlisted on the Charter, or whether the Charter will be inapplicable. ${ }^{104}$

This issue is not merely of academic interest since the transformation of the Charter into a binding document will bolster the position of 'the family' in the EU, by making it an institution worthy of special measures of protection. This is obvious from the fact that the Charter does not only include a classic provision (Article 7) enshrining the right to respect for family life, but also provides, in Article 33(1), that the family shall enjoy legal, economic and social protection. This latter provision is extremely important, especially in family reunification cases, since it illustrates that the Charter recognises that 'the family' in the EU has to be protected in its own right, and not only in the process of achieving other goals whether economic (such as the establishment of the internal market) or not. ${ }^{105}$ Accordingly, it remains to be seen how Article 51(1) of the Charter will be interpreted, and how far, if at all, this will enable the Community's human rights 'competence' to continue encroaching upon Member State sovereignty in the delicate area of immigration control.

Moreover, and somewhat ironically, this restrictive interpretation of the scope of the Charter is likely to give rise to new instances of reverse discrimination as regards the availability of human rights protection. This time, however, the discrimination will be exercised by the Union itself against some of its own citizens (those that wish to be accompanied by their family members in their State of nationality and residence) who will be treated worse than third-country-nationals lawfully resident in the EU who will wish to be accompanied in their State of permanent residence by their family members. This is because there is an EC Directive (see Directive on the right to family reunification, n 47 supra) governing the rights to family reunification of third-country-nationals residing in the EU who want to be accompanied by their family members in their State of lawful residence. Therefore, in cases which will involve the implementation of this Directive, the (third-country-national) claimants will be able to rely on the Charter in order to require the relevant Member State to respect their human rights as a matter of EC law; whereas in situations involving Union citizens who rely on EC law to be accompanied by their family members in their State of nationality and residence, the Charter will not be applicable as a check on whether the refusal of their Member State to grant them family reunification rights, violates their human rights. White has also pointed out that the fact that the Family Reunification Directive does not require thirdcountry-nationals to exercise inter-state movement in order to derive family reunification rights from EC law, whilst Union citizens must exercise such movement in order to derive such rights, 'could result in some anomalies. If the immigration rules of the Member State are restrictive, then it could result in third country nationals being treated more favourably than nationals [...] This could perpetuate - even extend - reverse discrimination....' - see R. C. A. White, 'Conflicting competences: free movement rules and immigration laws', (2004) 29 European Law Review 385, 395. For a similar view see A. Walter, n 19 supra, at p. 44. change or entrenching the status quo?', (2001) 26(6) European Law Review, 582, 587. 


\section{CONCLUSION}

This article has taken us through a journey over time in the Court's family reunification rights jurisprudence. The aim of the author has been to revisit a cluster of well-known cases in the area spanning over a period of thirty years, and, with the benefit of hindsight and taking as a point of reference the recent Eind, ${ }^{106}$ Metock ${ }^{107}$ and Sahin ${ }^{108}$ cases, provide a critical reassessment of the Court's reasoning in those cases. As has been explained, the Court in its recent case-law exhibits a tendency of following a more liberal approach towards the grant of family reunification rights, by bestowing such rights on moving Union citizens even where, in reality, there is no link between the need to grant those rights and the aim(s) of the EC provisions from which those rights are derived on the specific facts of the case. It has been suggested that the rationale behind this may have been the desire of the Court to protect the (human) right to family life of the Union citizens involved in the case; and that this may be part of a broader move towards developing a new principle according to which all moving Union citizens must have their human rights respected as a matter of EC law. Yet, and despite the attractiveness of this development, it has been argued that the application of this new principle will not be problem-free. On the one hand, it will aggravate the problem of reverse discrimination regarding the availability of EC human rights protection since, whilst it will reduce the number of instances of reverse discrimination, the cases of reverse discrimination that will continue to arise will be even more difficult to justify in view of the fact that the way that the scope of EC law is delimited under this new principle does not appear to be 'reasonable', in the sense of corresponding to one of the aims of the Community. On the other hand, the feasibility of this new approach in light of the possibility of the Treaty of Lisbon coming into force and its effect of making the EU Charter of Fundamental Rights binding, appears to be questionable, since the scope of application of the Charter is obviously narrower than the scope of application of EC human rights protection under this new principle and, in fact, may even be narrower than the current scope of EC human rights protection as developed in the Court's case-law. In any event, if the Court, despite the above concerns, wishes to continue applying this new principle requiring Member States to respect the human rights of all moving Union citizens, in the interests of legal certainty it should do so explicitly.

\begin{tabular}{ll}
\hline 106 & N 7 supra. \\
107 & N 8 supra. \\
108 & N 9 supra.
\end{tabular}

